\title{
DISCOURSE MOTIVATIONS OF MENTAL CONSTRUAL AND THE EXPRESSION OF STANCE IN SPEECH: A CASE STUDY OF ENGLISH
}

\author{
E.Yu. Khrisonopulo \\ Saint-Petersburg State University of Culture \\ 2, Dvortsovaya nab., Saint-Petersburg, Russia, 191186
}

\begin{abstract}
This paper presents an account of the phenomenon of mental construal manifested in English expressions of stance through the distinction of clauses that are headed by subjects associated with two conceptual archetypes: participant $(\mathrm{P})$ invoked by the first-person pronoun (I am certain that) and abstract setting (S) conveyed by anticipatory it (It is certain that). With recourse to the main theoretical points on the anchoring of linguistic meaning in the acts of speech activity (Leontiev A.A.), mental construal (Langacker R.), processes of discourse-driven conceptualization and categorization (Kubryakova E.S.) and with reference to discourse oriented studies of stance (Biber D., Finegan E., Kärkkäinen E.), the conducted analysis focuses on a corpus of about 350 examples that represent narrative and dialogic discourse in English-language fiction. As evidenced by linguistic data, the choice of stance expressions with P- and S-subjects is motivated, respectively, by the distinctions that arise in discourse between actual and mentally represented types of reality, the contrast between reference-making and viewing as types of cognitive events and the distinction between event-schemas and mental experiences. These discursively relevant distinctions are further shown to be related to narrative and dialogic strategies that are used in literary texts for the expression of stance with the alternative stance-clauses.
\end{abstract} operation

Keywords: mental construal, stance, discourse, speech, clausal subject, type of reality, cognitive

\section{INTRODUCTION: MENTAL CONSTRUAL IN THE DISTINCTION OF CONCEPTUAL ARCHETYPES}

One of the cognitive abilities that is regularly reflected in uses of linguistic items and expressions is mental imagery, or construal. According to the basic assumptions of cognitive grammar, as presented in R. Langacker (2000a; 2000b), mental construal consists in the ability to conceive and portray the same situation in alternate ways, with recourse to different linguistic means that evoke distinct facets of the described situation alongside such parameters as specificity, perspective, prominence, background and some others. There is convergent evidence that construal is involved in the meaning structure of a wide variety of linguistic expressions that can both convey some conceptual content and reflect one's subjective attitudes, or stances, towards that content. For instance, in English the expression of epistemic, perceptual and emotional stance can involve choosing between alternative stance clauses like those in (1), (2) and (3), respectively:

(1) I am certain that - It is certain that.

(2) I felt as if - It was as if.

(3) I am glad that - It is good that. 
The above clauses are treated among linguistic markers of stance in English which occur, according to the corpus studies of D. Biber and E. Finegan (1989), D. Biber, S. Johansson et al. (2004, p. 965-986), across a variety of styles and registers. As shown in the studies on the expression of stance in English conversation (Kärkkäinen, 2003; Kärkkäinen, 2006; Kärkkäinen, 2007; Keysanen, 2007), academic writing (Hyland, 2005; Hyland, Tse, 2005) and in various kinds of texts in different languages (Berman, 2004), the speaker's choices in communicating his or her positioning towards the content expressed are dependent on such factors as the type of discourse, the context and the interactive dimension of communication. These factors are analyzed in the studies on stance from the point of view of their relatedness to the meaning and functional properties of stance expressions taken as a whole and included into particular contexts of oral or written communication. However, the choice of composite expressions of stance like those in (1) - (3) may be influenced — to a greater or lesser degree — by a particular conceptual and/or communicative contribution of the expressions' constituents, such as clausal subjects and predicates (as suggested, for instance, in Langacker, 2000a, p. 152).

From a cognitive perspective, the contrast between the clausal subjects in (1) - (3), can be described as a distinction between two conceptual archetypes: participant and setting (Langacker, 1987). Generally, a conceptual archetype is defined in Langacker's theory of cognitive grammar (Langacker, 2000a, p. 24) as a conceptual structure which is grounded in experience and which includes various sorts of "the experience of perceiving, of thinking and of feeling emotions". It is assumed, according to the suggested view, that the conceptual archetype "participant" is a discrete dynamic entity, typically a person that plays a key role in the structuring of a (clausal) situation or event. The archetype "setting" in turn is characterized as a kind of location or region that has spatial and/or temporal extension. It is considered that this conceptual archetype can take the form of abstract setting, or mental expanse that delineates "a scope of awareness" in a particular context of discourse (Langacker, 2011, p. 206-208).

In examples (1) - (3), the first-person pronoun points to a participant, or stancetaker. On the other hand, anticipatory it indicates in each case the (respective) stancetaker's scope of awareness, or abstract setting. Consequently, the $I$ and the $i t$ in these examples are not entirely dissociated, but rather, related to each other metonymically: whereas the participant $[\mathrm{P}]$-pronoun $(I)$ invokes a person as the subject of judgmentmaking, the setting [S]-pronoun (it) makes reference to the person's mental sphere activated in a discourse. In actual usage events, a speaker can either choose between clauses headed by P- or S-subjects or use them alternatively, as in (4) and (5):

(4) You feel as if the whole universe were hostile [...]. Your feeling of security vanishes, and it seems that everything about your life is horribly brittle and destructible (Wilson C., The Mind Parasites, p. 125).

(5) It was interesting [...] to note that Fleischmann's obvious tenderness for her [...] communicated itself to Reich and myself [...]. I should also note that the lust experienced by Reich and myself was not the usual male desire to possess a strange female [...] (Wilson C., The Mind Parasites, p. 147).

Obviously in (4), the clauses headed by P- vs. S-subjects (you and it, respectively) convey very similar perceptual and epistemic stances of the $I$-narrator. In (5), the sim- 
ilarity of modal and emotional stances expressed by the clauses with it vs. $I$ is stressed through the use of also (in the second clause) as a marker of cohesion.

Alternative uses of clauses with P- and S-subjects are also to be found in dialogic interactions, as in the following fragment of conversation:

(6) '[...] But did you never have the feeling he got assistance from above as well as from the agents he afterwards acquired?'

'No. No, I never did. It never occurred to me.' (Le Carré J., The Spy who Came In from the Cold, p. 78).

The dialogue in (6) illustrates the case of alternations in the expression of uncertain supposition. Whereas the question is expressed by a P-subject clause (Did you never have the feeling), the answer contains both $\mathrm{P}$ - and S-subject clauses used synonymously (I never did. It never occurred to me).

The question that examples like (4), (5) and (6) posit is the motivation for the speaker-conceptualizer to start a stance-clause by invoking a stance-taker as a participant in the use of a referring expression (typically a personal pronoun) or by the implicit reference to the stance-taker's scope of awareness, or setting, in the use of non-referential anticipatory it.

\section{AIMS, DATA AND THEORETICAL PREREQUISITES OF THE STUDY}

The aim of the proposed paper is to reveal the nature and discourse motivations of mental construal manifested in choosing the above mentioned stance-clauses headed by either P- or S-subjects. To this end, the following questions are addressed: (1) the discursively relevant facets of the conceptual content that are invoked through alternations of P- and S-subjects; (2) the nature of contextual factors that make the use of a particular stance-clause felicitous or non-felicitous.

With the general discourse orientation of the study, the paper takes up the following theoretical points: (a) the assumption on the anchoring of linguistic meaning in the acts of speech activity that is structured by motives, purposes and speech performance as such, with the latter constituted by speech actions and speech operations (Leontiev, $1975 ; 1981 ; 2006 a ; 2006 b)$, including sign operations of designation, or giving a name, and predication, or attributing a property to a designated thing or phenomenon (Kubryakova, 1986); (b) the assumption on the role of the processes of discourse-driven conceptualization and categorization in making choices of linguistic items for the generation of utterances (Kubryakova, 2004; 2012); (b) the claims substantiated in S. Garrod and M.J. Pickering (2004; 2013), J. Stewart, O. Gapenne and E.A. Di Paolo (2010) on the crucial role of dialogic interactions and coordinating activities in the generation, shaping and enactment of meaning, in particular linguistic meaning, as shown in D. Bottineau (2010).

The proposed analysis is based on data that come from literary texts, namely, the detective novel "The Spy who Came In from the Cold" by John Le Carré (2000), the book of stories "The Rendezvous and Other Stories" by Daphne Du Maurier (2008) and the philosophical and psychological novel "The Mind Parasites" by Colin Wilson (2000). The overall corpus of correlative stance-clauses like those in (1) - (3) includes about 350 examples that occur both in dialogical and narrative parts of the texts. 
Generally, stance expressions in which the speakers (including the $I$-narrator) pronounce their judgments about the described events are used rather frequently in all the mentioned texts. In some cases the correlative clauses occur in different parts of narration, which implies the narrator's choice of one available expression over another one, as it happens in (7) and (8):

(7) Next morning, at breakfast, we were glad to see that Fleischman was in sparkling spirits (Wilson C., The Mind Parasites, p. 113).

(8) It was a pleasure to see how quickly he became transformed - to watch the energy and optimism straightening his shoulders and taking the lines out of his face (Wilson C., The Mind Parasites, p. 228).

Similarly, one of the alternative stance clauses may be chosen in dialogic discourse, as shown in (9) and (10):

(9) 'I know what you are going to tell me. But did you never have the feeling he got assistance from above as well as from the agents he afterwards acquired?' (Le Carré J., The Spy who Came In from the Cold, p. 78).

(10) 'Was it your impression that the agent had been operating for some time before the first payment was made? [...]' (Le Carré J., The Spy who Came In from the Cold, p. 87).

The analyzed texts also contain more subtle cases like (4), (5) and (6) mentioned previously and the one in (11) where the stance-clauses with the P-and S-subjects ( $I$ and $i$, respectively) co-occur in two subsequent clauses:

(11) That evening [...] I was feeling a little lonely, and was glad to talk. Even the subject of the excavations had ceased to be unbearable to me, and it gave me pleasure to tell him the "inside story of our work (Wilson C., The Mind Parasites, p. 60).

In (11), the choice of the stance-clauses with P-and S-subjects is accompanied by the explicit contrast of the latter, which may be indicative of some discursively relevant cognitive distinctions.

In addressing the previously mentioned research questions the subsequent analysis of linguistic data in section 3 focuses on the following two issues: (a) the possibilities of the communicative and syntactic structuring of stance-clauses with the chosen P- $v$. S-subjects; (b) the discursive motivations and/or purposes that underlie the choice and (sometimes) contrastive uses of clauses.

\section{THE PARTICIPANT-SETTING DISTINCTION IN THE CONTEXT OF SPEECH ACTIVITY}

The regularities of the communicative perspective and the syntactic sequencing of a clause with a chosen subject (here: $\mathrm{P}$ or S) are reflected both in the choice of linguistic items that collocate with the subject in question and in the potential for the discursive structuring of the content conveyed.

\subsection{Predications with P- vs. S-subjects: felicity conditions and constraints}

The choice of linguistic units and their sequencing in predications with P- and Ssubjects manifest three important distinctions. 
First, predications that can be attributed to P- and S-subjects are not totally identical in the expression of epistemic stance. Similarities between the respective clauses are usually fairly obvious in cases of expressing the epistemic state of belief or certainty, as in (12):

(12) I am convinced / believe that - It is my conviction / belief that.

The alternation of stance-clauses in the expression of the stance-taker's certainty occurs, for instance, in (13) where the speaker switches from the P-subject clause (we have become convinced that) to the one with the S-subject (it is our conviction that):

(13) "But in recent weeks we have become convinced that we are facing something far more dangerous than a curse. It is our conviction that we have disturbed the sleep of forces that once dominated the earth [...]." (Wilson C., The Mind Parasites, p. 154).

However, the epistemic state of (one's individual) knowledge or doubt can be attributed only to a P-subject (such as $I$ ), but not to the S-subject, expressed by anticipatory it, $c f$ :

(14) I know / doubt that — *It is my knowledge / doubt that.

The demonstrated constraint shows that the S-subject it which invokes a stancetaker's scope of awareness, or mentally represented region, cannot be equated with the actual state of affairs that makes the content of one's knowledge or doubt. On the other hand, as shown in (12) and (13), mentally represented content that underlies a person's convictions or beliefs can be easily attributed to anticipatory it. To put it more generally, the choice of a stance-clause with a P-vs. S-subject in a discourse presupposes one of the formats in which a subsequent proposition is regarded: the format of actual reality (with a P-subject) or mentally represented reality (with the S-subject it).

Second, using a P-subject in a stance-clause always involves the operation of reference-making to a stance-taker. Reference-making is always in a communicative focus of a P-subject clause and the use of negation in such a clause entails a change of reference. Thus, a negative transformation of (15) in (16) results in negating the expressed epistemic stance and in switching to another stance-taker:

(15) "I'm not sure, but I think we got a response." (Wilson C., The Mind Parasites, p. 227).

(16) "I don't think we got a response."

By contrast, applying negation to the stance-clause it seems which is very close to I think in terms of the epistemic attitude expressed does not entail a change of the mental structure signified by it, $c f$ :

(17) It now seems absurd that neither of us anticipated the consequences of our discovery (Wilson C., The Mind Parasites, p. 43).

(18) It doesn't seem absurd that neither of us anticipated the consequences of our discovery.

In (18), the negative particle not bears on the attributed stance (does not seem absurd) and on reference to the implied stance-taker ( 'it' does not seem absurd to someone). However, the S-subject it evokes the same scope of mental awareness. In both (17) and (18), anticipatory it identifies the activated mental sphere as a whole, which is followed 
by its further specification through the attributed stance (seems / does not seem absurd) and the subsequent complement clause. What comes into a communicative focus with the S-subjects here is the way the mentally represented picture $(i t)$ is identified through a particular epistemic positioning. Therefore, the choice between the expression of stance with P- and S-subjects in (15) and (17) is dependent on a discursively relevant distinction between the operations of reference (with P-subjects) and identification (with S-subjects).

Third, predications that can be attributed to P- $v s$. S-subjects differ in the way they are elaborated in representing a stance-taking event. Thus, P-subjects activate a typical schema of an event that has a temporal slot. In a P-subject stance-clause the slot can be filled by a temporal expression that refers to a particular point in time when the event happened, for instance:

(19) But half an hour later I felt as though my mind was supporting a load the size of Mount Everest (Wilson C., The Mind Parasites, p. 26).

In (19), the adverbial half an hour later puts the stance-taking event I felt on a temporal plane with respect to another event described in the text.

Unlike P-subjects, anticipatory it invites a stance-predication that can specify a way in which the stance-taking event is internally experienced by the stance-taker. One of the most frequent experiences that happened to the I-narrator of C. Wilson's novel was that of unexpectedness. This is reflected in frequent uses of the adverb suddenly in Ssubject clauses, as in (18):

(20) It was suddenly as if we were in the middle of the noisiest crowd the world has ever known (Wilson C., The Mind Parasites, p. 231).

The distinction manifested in the attribution of very similar perceptual stances to Pvs. S-subjects (I felt as though - It was as if) in (19) and (20) points to the stancetaker's choice between a participant as a constituent of an event-schema (alongside its other constituents including temporal ones) and abstract setting (or scope of mental awareness) as a constituent of an internal experience.

All the three mentioned distinctions between P- and S-subjects occur in the acts of attributing stance-predications to them in discourse. Given that any discursive or utterance-generation event presents a systemic whole that is driven (as shown, for instance, in E.V. Sidorov $(2009 ; 2011)$ with reference to linguistic material) by the mechanism of mutual alignment and coordination of the speaker-addressee speech activities, choosing one of the mentioned discursively relevant facet associated with the participantsetting distinction would also point to a contextually anchored communicative choice of the stance-taker.

\subsection{The factor of adjustment to the utterance comprehension in choosing between P- vs. S-subjects}

There are two addressees of the stance-taker's speech activity that are presupposed in the analyzed texts and whose comprehension (presenting also a type of speech activity) is at issue: one is a (generalized) reader of the text and the other is a fictional character involved in a dialogue with another character (including the $I$-narrator). Ensuring the comprehension of the stance-taker's positioning on the part of both addressees is effect- 
ed through the stance-taker's resort to communicative techniques that are adjusted to the context in which a particular stance is expressed. The language of the texts allows to distinguish three basic communicative factors that motivate the choice of P- or Ssubjects in the expression of stance. It will be shown below that all these factors are directly related to the three mentioned distinctions between the respective conceptual archetypes.

First, by enacting the actuality format of reality in using a P-subject the stancetaker emphasizes the factivity status of the stance-taking event as a whole. By contrast, the use of the S-subject it amounts to the activation of the focus of attention in one's positioning towards a certain state of affairs described in the subsequent clause. The distinction between the communicative strategy of actualizing one's stance $v s$. that of establishing the focus of attention can be the source of rhetorical effects in oral speech, as in (21):

(21) And now Fleischman suddenly remarked:

"We've learned one interesting thing about the parasites. It's wrong to think of them as existing in some kind of space. The crowd attacking me here must have been more or less the same crowd who were attacking you two in Diyarbakir [...]."

This had also struck myself and Reich earlier. But Fleischman saw another consequence.

"In that case, we're mistaken to think about the mind in terms of physical space. [...]. They don't have to travel to get from here to Diyarbakir. They are already in both places at once." (Wilson C., The Mind Parasites, p. 143).

In (21), the alternation in the expression of the same epistemic truth positioning with S- and P-subjects (it's wrong to think - we're mistaken to think) allows the stancetaker to switch from the summary mental image in the stance-taking event (it) to the actual stance-taker (we) who is supposed to take (further) steps on the basis of the actual positioning.

The actualization of the stance-taker's positioning may also be important in the expression of emotion, as in the following example:

(22) 'He tried to kiss me, and was, well, rather rough. I was so surprised that I wasn't prepared, you see, and - Oh, I hate telling you all this!' (Du Maurier D., Leading Lady (Stories), p. 153).

The example in (22) describes a situation with two participants (referred to as he and $I$ ). The communicative necessity to present both participants as equally involved in the described situation motivates the use of a P-subject $(I)$ in the expression of stance: I was surprised that.

Unlike (22), the example in (23) has only one prominent participant - the girl mentioned at the start of the initial sentence. The stance-taker, Mrs. Ellis, who is making judgments about the girl is represented with a lesser degree of salience. This motivates the establishment of the focus of attention (it) rather than making direct reference to the stance-taker in the expression of surprise (it was a wonder):

(23) An ignorant, silly sort of girl, thought Mrs. Ellis. It was a wonder she had passed her test into the force. She thought they only employed intelligent women (Du Maurier D., Split Second (Stories), p. 261). 
The actualization of one's stance acquires a high degree of relevance when the expressed subjective positioning is no less important than situations to which a particular stance is taken. For instance, in (24) the speaker's emotional stance of relief is actualized through self-reference as a participant $(I)$ in a highly emotional situation:

(24) 'I'm sincerely relieved he is not on the committee,' stated the Very Reverend Travers. It would put us all in a very embarrassing position. I feel it my duty to inquire into the whole business. [...]' (Du Maurier D., Adieu Sagesse, p. 74).

In the given example the speaker is emotionally involved in the described situation, which is conveyed lexically by means of words and expressions referring to emotions (such as "be relieved", "feel", "a very embarrassing position"). On the other hand, in cases when it is a particular state of affairs which is at issue, rather than a stance towards the described situation, the choice of a stance clause with it appears to be more appropriate, as in (25):

(25) They would shoot Fiedler; that's what the woman said. Why did it have to be Fiedler - why not the old man who asked the questions, or the fair one in the front row between the soldiers, the one who smiled all the time [...]. It comforted her that Leamas and Fiedler were on the same side (Le Carré J., The Spy who Came In from the Cold, p. 202).

Second, the distinction between the operations of reference-making and identification involved in the differentiated uses of P- and S-subjects is usually triggered off by the stance-taker's dialogic choice between subjectivizing the reported stance in the first case and, on the contrary, objectivizing the stance in question by giving it a general identification (it). For instance, in (26), the epistemic event of mental apprehension (began to see) is presented with reference to specific individuals (we), which is aimed at establishing (cohesive) links with other individual events happening to the characters involved:

(26) Reich said: "But if the parasites are between you and the source, they're probably obstructing you somehow."

We now began to see that this was a real possibility. The parasites had always used this "obstructing" method [...]. We had learnt how to prevent this: by penetrating to those depths of the mind from which the parasites normally operated." (Wilson C., The Mind Parasites, p. 194).

Contrastively to (26), the description of a similar epistemic event in a clause with the S-subject it (it became clear) in (27) is motivated by the dialogic technique of sharing the activated mental picture (it):

(27) It became clear that there is a fundamental mistake about ordinary human existence - as absurd as trying to fill a bath with the plug out, or driving a car with the hand brake on (Wilson C., The Mind Parasites, p. 100).

The use of anticipatory it in the above example fits the generic construal of the situation described in the subordinate clause and contributes to its presentation in a more objective manner. 
The use of anticipatory it for objectivizing one's stance is communicatively significant when the scope of mental awareness is intended to be shared by the participants of a conversation, as in (28):

(28) 'Darling, it's good to be alive, isn't it? We're going to be happy, you and I, happyhappy.' (Du Maurier D., The Closing Door (Stories), p. 197).

In (28), the dialogic appeal of the speaker (and stance-taker) is meant to activate one commonly shared mental picture (it) that can be negotiated or discussed (isn't it). In this context, the stance-taker's possible self-reference through the use of the pronoun we (We are happy to be alive, aren't we?) would subjectivize the expressed positive stance and would sound less interactively oriented. On the other hand, when a stancetaker's positive positioning cannot be the object of discussion, as in self-presentation in (29), the use of the requisite personal pronoun becomes the only possibility:

(29) I I am pleased to present myself, Fritz Lieber, secretary of the International Society of Letters. Welcome to Geneva.' (Du Maurier D., The Rendezvous (Stories), p. 119).

The contrast between clauses with P- and S-subjects as manifestation of the distinction between the discourse strategies of subjectivizing vs. objectivizing one's speech is also obvious in cases when the subjects are followed by modal predicates. Thus, the attribution of the modal predicate should think to the P-subject $I$ in (30) serves to convey the uncertainty of the specific speaker in the expression of his epistemic positioning:

(30) '[...] Your car turned into Bywater Street and our agent reported that you were dropped at number nine. That happens to be Smiley's house.'

'That's drivel,' Leamas declared. 'I should think I went to the Eight Bells; it's a favorite pub of mine' (Le Carré J., The Spy who Came In from the Cold, p. 180).

Owing to the specific reference of the P-subject $I$ in the above example the stance clause with the modal predicate as a whole (I should think) is understood as a specific subjective positioning of the speaker. By contrast, the collocation of anticipatory it with a modal predicate in a correlative epistemic clause (it would seem) in (31) has no individualizing effects:

(31) Annette Limoges lived, it would seem, only to retain what Scrivener cared to send her [...] (Du Maurier D., The Rendezvous (Stories), p. 102).

The context of free indirect discourse representing the character's inner speech in which the above example occurs suggests that this very character (Scrivener) is the subject of the mentioned epistemic positioning. However, similar to the uses of it as S-subjects in (21), (23) and (25) the use of the pronoun in this case introduces a summary mental picture, which activates the interpretation of the subsequent modal predicate (would seem) as referring to the way the picture could be imagined independently of one's individual perceptions. This kind of interpretation invites the alignment of any (potential) reader with the expressed stance.

Third, the distinction between P- and S-subjects as constituents of event-schemas $v s$. those of internal experiences acquires communicative significance through the stancetaker's choice of either reporting a stance-event by filling its "slots", including a participant's slot, or commenting on this event by focusing on the activated mental sphere (it) 
and specifying the nature of experience in the stance-predication. As mentioned previously, the reporting mode of presenting a stance-event helps to associate its participant with the temporal location of the event in question and thus - to connect all the events in a network of their dynamic interrelationships. Thus, similar to the case in example (19), the report of a stance-event with the P-subject he in (32) allows to describe the event in question ("having an idea") in a series of other events that follow each other in a temporal sequence:

(32) Too agitated to remain on the balcony, he went back into his room, and flinging himself in a chair began to read over the notes for his lecture. It was no use, though. He could not concentrate. Then he had an idea that she might, after all, have arrived back at the hotel [...] (Du Maurie D., The Rendezvous (Stories), p. 106).

The epistemic experience of having an idea in the above example is presented as one event in a chain of others: the character (he) went back into his room, began to read over the notes, could not concentrate, had an idea that. The description of a similar epistemic state by a clause with anticipatory it (it occurred to him) produces somewhat different narrative effects:

(33) A third martini did little to calm him; being a moderate drinker at all times, this sudden taking to spirits produced an intensity of fever. It occurred to him that some disaster might have overtaken her [...] (Du Maurie D., The Rendezvous (Stories), p. 107).

The clause with anticipatory it in the above example does not relate the described epistemic state to the previously mentioned internal experience (the character's feeling "an intensity of fever"), but rather, introduces a comment on that experience.

Similar to (32), the use of a P-subject clause in (34) helps to present the experienced perceptual stance (felt as if) as directly related (here: through a causal link) to the previously mentioned event:

(34) And then the realization came to me with such searing force that I felt as if I had been struck by lightning (Wilson C., The Mind Parasites, p. 72).

Unlike (34), a comment on a similar perceptual stance-event in (35) motivates the choice of a clause with the S-subject (it was as if), which, again, places the focus on the activated domain of mental awareness (it) and zooms in on the event, rather than relates it to the previously mentioned one:

(35) To begin with, the Graus protested "One at a time." Then, suddenly, it was as if we fell into step with Reich [...]. (Wilson C., The Mind Parasites, p. 146).

Despite the use of the temporal indicator then in the above example, there is no obvious temporal link with the previously mentioned event, but rather, a close look at (or a comment on) the internal perceptual experience.

The discussed contrast between clauses with P- and S-subjects as associated with the distinction between event-frames and internal experiences, respectively, is reflected in different functions of the adverb now in these clauses. Thus, the use of now in a P-subject clause, as in (36), puts the described epistemic event (was aware) on a temporal plane with respect to the previously mentioned event (he said):

(36) "You know," he said, and he was aware now that his words were a little slurred (Du Maurier D., The Rendezvous (Stories), p. 110). 
The use of now with the preceding and in the above example signals that there is a point in time (now) that separates the stance event (he was aware) from the prior speech event (he said). This use of now fits the definition of the adverb that is formulated in Cambridge Dictionary of the English Language in the following way: "used in stories or reports of past events to describe a new situation or event" (Cambridge Online: http://dictionary.cambridge.org/dictionary/english/now).

Unlike (36), the use of now in the example below introduces the point at which the prior event(s) are interpreted rather than located in a temporal sequence:

(37) London must have gone raving mad. He'd told them - that was the joke - he'd told them to leave her alone. And now it was clear that [...] from the very moment he left England [...] some fool had gone round [...] paying the bills, settling the grocer, the landlord; above all Liz (Le Carré J., The Spy who Came In from the Cold, p. 191).

In (37), the clause with anticipatory it construes the epistemic positioning of the character (it was clear that) as an internal experience where now marks the point of mental apprehension which results from the analysis of the prior event (he'd told them to leave her alone). In this context, the adverb now can be defined in the following way: "used when describing a situation that is the result of what someone just said or did" (Cambridge Dictionary Online: http://dictionary.cambridge.org/dictionary/english/now). The connotation of result that is introduced by now into the sentence as a whole comes from the implication of mental awareness and the associated sense of mental processing, or analysis, that is activated by anticipatory it in this discursive context. The connotation of analysis, in turn, contributes to the realization of narrative strategy of commenting on the epistemic experience by contrast with the strategy of reporting a similar experience (it was clear that - he was aware that) in a temporal sequence.

\section{CONCLUSION}

The conducted study of alternations in uses of stance-clauses headed by subjects that refer to either participants or abstract setting as two distinct types of conceptual archetypes has shown that cognitive differences between the linguistic units signifying the two conceptual structures (typically, personal pronouns $v s$. anticipatory $i t$ ) are rooted in the discursively relevant facets of these structures and are motivated in actual discourse by communicative distinctions made in the context of speech. It has been established that the choice of stance expressions with participant- and setting-subjects is motivated, respectively, by the distinctions that arise in discourse between actual and mentally represented types of reality, the contrast between reference-making and viewing as types of cognitive events and the distinction between event-schemas and mental experiences. As evidenced by linguistic data, these discursively relevant distinctions are related to narrative and dialogic strategies that are used in literary texts for the expression of stance with the alternative stance-clauses.

(C) Ekaterina Khrisonopulo, 2017 


\section{REFERENCES}

Кубрякова Е.С. Номинативные аспекты речевой деятельности. М.: Наука, 1986. [Kubryakova E.S (1986). Nominativnyi aspekt rechevoi deyatel'nosti. Moscow: Nauka. (In Russ).]

Кубрякова Е.С. В поисках сущности языка. Когнитивные исследования // Институт языкознания PAH. М.: Знак, 2012. [Kubryakova E.S. (2012) V poiskakh sushchnosti yazyka. Kognitivnye issledovaniya / Institut yazykoznaniya RAN. Moscow: Znak. (In Russ).]

Кубрякова Е.С. Язык и знание: на пути получения знания о языке: части речи с когнтивной точки зрения. Роль языка в познании мира // Институт языкознания РАН. М.: Языки Славянских культур, 2004. [Kubryakova E.S. Yazyk $i$ znaniye: Na puti polucheniya znanij o yazyke: Chasti rechi s kognitivnoj tochki zreniya. Rol' yazyka v poznanii mira / Institut yazykoznaniya RAN. Moscow: Yazyki Slavyanskikh Kultur. (In Russ).]

Сидоров Е.В. Онтология дискурса. 2-е изд. М.: Либроком, 2009. [Sidorov E.V. (2009). Ontologiya diskursa. 2nd ed. Moscow: Librokom. (In Russ).]

Сидоров Е.В. Порядок текста. М.: Российский государственный социальный университет, 2011. [Sidorov E.V. (2001). Poryadok teksta. Moscow: Russian State Social University. (In Russ).]

Berman, R.A. (2004). Introduction: developing discourse stance in different text types and languages. Journal of Pragmatics, 2004, 37, 105-124.

Biber, D. and Finegan, E. (1989). Styles of stance in English: lexical and grammatical marking of evidentiality and affect. Text, 9(1), 93-124.

Biber, D., Johansson, S., Leech, G., Conrad, S. and Finegan, E. (2004). Longman grammar of spoken and written English. Harlow: Pearson Education Limited.

Bottineau, D. (2010). Language and enaction. In Stewart J., O. Gappenne, E. Di Paolo (eds.). Enaction: toward a new paradigm of cognitive science. Cambridge: The MIT Press. 267-306.

Du Maurier, D. (2006) The rendezvous and other stories. Great Britain: Virago Press.

Garrod, S. and. Pickering, M.J. (2004). Why is conversation so easy? Trends in Cognitive Sciences, $8,8-11$.

Garrod, S. and Pickering, M.J. (2013). Interactive alignment and prediction in dialogue. In Wachsmuth I., J. de Ruiter, P. Jaecks and S. Kopp (eds.). Alignment in communication: towards a new theory of communication. Amsterdam. Philadelphia: John Benjamins. 193-203.

Hyland, K. (2005). Stance and engagement: A model of interaction in academic discourse. Discourse Studies, 2005, 7(2), 173-192.

Hyland, K. and P. (2005). Tse Evaluative 'that' constructions: signalling stance in research abstracts. Functions of Language, 12(1), 39-63.

Kärkkäinen, E. (2003). Epistemic stance in English conversation: a description of its interactional functions, with a focus on 'I think'. Amsterdam: John Benjamins.

Kärkkäinen, E. (2006). Stancetaking in conversation: from subjectivity to intersubjectivity. Text and Talk, 26(6), 699-731.

Kärkkäinen, E. (2007). The role of 'I guess' in conversational stancetaking. In Englebretson R. (eds.). Stancetaking in discourse: subjectivity, evaluation, interaction. Amsterdam / Philadelphia: John Benjamins, $183-219$.

Keysanen, T. (2007). Stancetaking as an interactional activity: challenging the prior speaker. In Englebretson R. (eds). Stancetaking in discourse: subjectivity, evaluation, interaction. Amsterdam / Philadelphia: John Benjamins, 253-282.

Langacker, R.W. (1987). Grammatical ramifications of the setting / participant distinction. In Proceedings of the $13^{\text {th }}$ BLS Annual Meeting, 383-394.

Langacker, R.W. (2000a) Grammar and conceptualization. Berlin; New York: Mouton de Gruyter, 2000a. 
Langacker, R.W. (2000b). Why a mind is necessary: conceptualization, grammar and linguistic semantics. In Albertazzi, L. (ed.). Meaning and cognition: a multidisciplinary approach. Amsterdam / Philadelphia: John Benjamins, 25-38.

Langacker, R.W. (2011). On the subject of impersonals. In Brdar M., S.Th. Gries, M.Ž. Fuchs (eds.). Cognitive linguistics: convergence and expansion. Amsterdam / Philadelphia: John Benjamins, $179-217$.

Le Carré, J. (2000). The spy who came in from the cold. Great Britain: Coronet Books, 2000.

Leontiev, A.A. (2000). The heuristic principle in the perception, emergence, and assimilation of speech. In Lenneberg Eric H. and Elizabeth Lenneberg (eds). Foundations of language development: a multidisciplinary approach. Paris: The UNESCO Press, 1975. 43-58.

Leontiev, A.A. (1981). Sign and activity. In Wertsch J.W. (eds). The concept of activity in Soviet psychology. New York: M.E. Sharpe, Inc., Publisher, 241-255.

Leontiev, A.A. (2006a). Psycholinguistic units and speech generation. Journal of Russian and East European Psychology, 2006a, 44 (4), 7-88.

Leontiev, A.A. (2006b). Units and levels of activity. Journal of Russian and East European Psychology, 44 (3), 30- 46.

Stewart, J., O. Gapenne and E.A. Di Paolo (eds.). Enaction: toward a new paradigm of cognitive science. Cambridge: The MIT Press, 2010. XVIII.

Wilson C. The mind parasites. Moscow: Manager, 2000.

\section{Article history:}

Received: 21 September 2016

Revised: 20 October 2016

Accepted: 02 December 2016

\section{For citation:}

Khrisonopulo, Ekaterina (2017). Discourse Motivations of Mental Construal and the Expression of Stance in Speech: a Case Study of English. Russian Journal of Linguistics, 21 (1), 91-104.

\section{Bio Note:}

Ekaterina Khrisonopulo, $\mathrm{PhD}$, Associate Professor of Department of Foreign Languages and Linguistics, Faculty of World Culture at Saint-Petersburg State University of Culture. Research interests: Discourse Analysis, Cognitive Linguistics, Psycholinguistics, Language and Culture, Axiology. Contact information: e-mail: hrisonopulo@mail.ru

DOI: 10.22363/2312-9182-2017-21-1-91-104

\section{ДИСКУРСИВНЫЕ ФАКТОРЫ МЕНТАЛЬНОЙ ДИФФЕРЕНЦИАЦИИ \\ И ВЫРАЖЕНИЕ ПРОПОЗИЦИОНАЛЬНОЙ УСТАНОВКИ В РЕЧИ (на материале английского языка)}

\section{Е.Ю. Хрисонопуло}

Санкт-Петербургский государственный институт культуры

2, Дворчовая набережная, Санкт-Петербург, Россия, 191186

В статье представлен анализ явления мыслительной дифференциации, которая может выражаться в английском языке при передаче пропозициональной установки путем разграничения конструкций с подлежащими, ассоциируемыми с двумя концептуальными архетипами: «партиципан- 
том» (П), на который указывает местоимение I лица (I am certain that), и «абстрактным сеттингом» (C), выражаемым вводным местоимением it (It is certain that). При опоре на основные теоретические положения об обусловленности языкового значения актами речевой деятельности (А.А. Леонтьев), ментальной дифференциации (Р. Лэнекер), процессами дискурсивно мотивированной концептуализации и категоризации (Е.С. Кубрякова), а также с учетом имеющихся дискурсивно ориентированных исследований выражения установки (Д. Байбер, Э. Финеган, Е. Карккаинен) в работе анализируются примеры (общим объемом около 350), представляющие нарративный и диалогический дискурс в текстах англоязычной художественной литературы. Языковые данные свидетельствуют в пользу того, что выбор конструкции пропозициональной установки с подлежащими П либо С мотивируется, соответственно, различиями, возникающими в дискурсе, между фактической и мысленно репрезентированной реальностью, противопоставлением референции и наблюдения как типов когнитивных операций, а также разграничением событийных схем и мысленных представлений. В работе показано, что данные дискурсивно значимые различия непосредственно связаны с нарративными и диалогическими стратегиями, которые используются в художественных текстах для выражения пропозициональной установки в предложениях с различными типами подлежащих.

Ключевые слова: ментальная дифференциация, установка, дискурс, речь, подлежащее, тип реальности, когнитивная операция

\section{История статьи:}

Дата поступления в редакцию: 21 сентября 2016

Дата принятия к печати: 02 декабря 2016

\section{Для цитирования:}

Khrisonopulo, Ekaterina. Discourse Motivations of Mental Construal and the Expression of Stance in Speech: a Case Study of English // Вестник Российского университета дружбы народов. Серия: Лингвистика. 2017. Т. 21. № 1. С. 91-104.

\section{Сведения об авторе:}

Хрисонопуло Екатерина Юрьевна, кандидат филологических наук, доцент кафедры иностранных языков и лингвистики Санкт-Петербургского государственного института культуры. Сфера научных интересов: социолингвистика, лингвокультурология, анализ дискурса, аксиологическая лингвистика. Контактная информация: e-mail: hrisonopulo@mail.ru 